\title{
Antibacterial evaluation and molecular properties of pyrazolo[3,4-b] pyridines and thieno $[2,3-b]$ pyridines
}

\author{
Mervat A. Elsherif ${ }^{1,2^{*}}$ \\ ${ }^{1}$ Chemistry Department, College of Science, Jouf University, P.O. Box: 2014, Sakaka, Saudi Arabia \\ ${ }^{2}$ Food Technology Research Institute, Agriculture Research Center, Giza, Egypt
}

\author{
ARTICLE INFO \\ Received on: 06/12/2020 \\ Accepted on: 11/02/2021 \\ Available online: 05/06/2021

\section{Key words:} \\ Pyrazolo[3,4- $b]$ pyridine, \\ thieno[2,3-b]pyridine, \\ antibacterial activity, \\ molecular properties, drug- \\ likeness.
}

\begin{abstract}
A series of pyrazolo[3,4-b]pyridines $(\mathbf{6 a - h})$ and thieno[2,3-b]pyridines $(\mathbf{8 a - h})$ was synthesized for the evaluation of their in vitro antibacterial activities against four bacteria species (namely Bacillus subtilis, Staphylococcus aureus, Escherichia coli, and Pseudomonas aeruginosa) and compared the result with the standard drug (Tetracycline). The result of the antibacterial evaluation showed that some pyrazolo[3,4-b]pyridines and thieno[2,3-b]pyridines display moderate antibacterial activity against the four bacteria species in this study. Furthermore, the physicochemical, pharmacokinetic, and drug-likeness properties were carried out using SwissADME website. The results of molecular properties show that all the pyrazolopyridines 6a-h and thienopyridines 8a-h showed agreement with the Lipinski and Veber rules. The two pyrazolo[3,4-b]pyridines $\mathbf{6 b}$ and $\mathbf{6 c}$ are almost in the range of the bioavailability radar pink area. Also, pyrazolo[3,4-b]pyridine derivatives 6a-h show high gastrointestinal absorption, all the derivatives except 6c are nonsubstrates for P-glycoprotein, and most of the derivatives show CYP isoform inhibition. This study could be valuable in the discovery of a new series of drugs.
\end{abstract}

\section{INTRODUCTION}

Treatment of infectious diseases remains a worldwide problem because of the increasing multidrug resistance caused by human pathogenic microbes. Therefore, the design of new compounds acting as antibacterial agents is an essential approach to overcome the problem of drug resistance (Shaaban et al., 2019).

Nitrogen heterocyclic compounds (triazine, benzimidazole, pyrazolopyrimidine, pyrazoloquinazoline, pyrazole, pyrazoline, and pyrazolo $[3,4-d][1,2,3]$ triazine) are very important classes of compounds owing to their widespectrum of biological activities (Abd El-All et al., 2016; Adole et al., 2020; Chobe et al., 2014; El-Naggar et al., 2018; Hassan et al., 2016, 2017, 2018; Jian et al., 2020; Magd-El-Din et al., 2018). In particular, pyrazolo[3,4-b]pyridines and thieno[2,3-b] pyridines (Elneairy et al., 2000; Mohi-El-Deen et al., 2019;

\footnotetext{
${ }^{*}$ Corresponding Author

Mervat A. Elsherif, Chemistry Department, College of Science, Jouf University, P.O. Box: 2014, Sakaka, Saudi Arabia; Food Technology Research Institute, Agriculture Research Center, Giza, Egypt. E-mail: Maelsherif@ju.edu.sa
}

Ravula et al., 2020; Saeedi et al., 2020) and 5-acetyl-4-amino-1(1,2,4-triazin-3-yl)-pyrazolo[3,4-b]pyridine derivative I showed antibacterial activity with good inhibitions against Staphylococcus aureus and Staphylococcus epidermidis (Ali, 2009). 4-Amino7,8-dihydropyrido[2',3':3,4]pyrazolo[5,1-c]-1,2,4-triazin-3,9dicarbonitrile II exhibited a remarkable cytotoxic activity against MCF-7 (ER $\alpha$-dependent) cells (Nafie et al., 2020). Also, $N-(6-(2,6-$ dichloro-3,5-dimethoxyphenyl)-1 $H$-pyrazolo[3,4-b]pyridin-3-yl) benzamide derivative III showed potent and selective Fibroblast growth factor receptor (FGFR) kinase inhibitors (Zhao et al., 2016).

On the other hand, 4-methyl-6-phenyl-thieno[2,3-b] pyridine-2-carbonitrile IV as an example of thieno[2,3-b]pyridine derivatives exhibited a promising growth inhibitory effect toward hepatocellular carcinoma (HepG-2) and breast cancer (MCF-7) lines (Hassan et al., 2019). 6-(Thiophen-2-yl)-4-(trifluoromethyl) thieno[2,3-b]pyridin-3-amine $\mathbf{V}$ showed promising antibacterial activity against Gram-positive Bacillus subtilis (Kumar et al., 2017) and 3-amino-5-bromo-4,6-dimethyl- $N$-(4-sulfamoylphenyl) thieno[2,3-b]pyridine-2-carboxamide (VI) showed potent cytotoxicity against five human cancer cells lines, namely, breast adenocarcinoma (MCF7), hepatocellular carcinoma (HepG2), colon adenocarcinoma (HCT116), nonsmall lung (A549), and prostate (PC3) (Naguib and El-Nassan, 2016) (Fig. 1). 


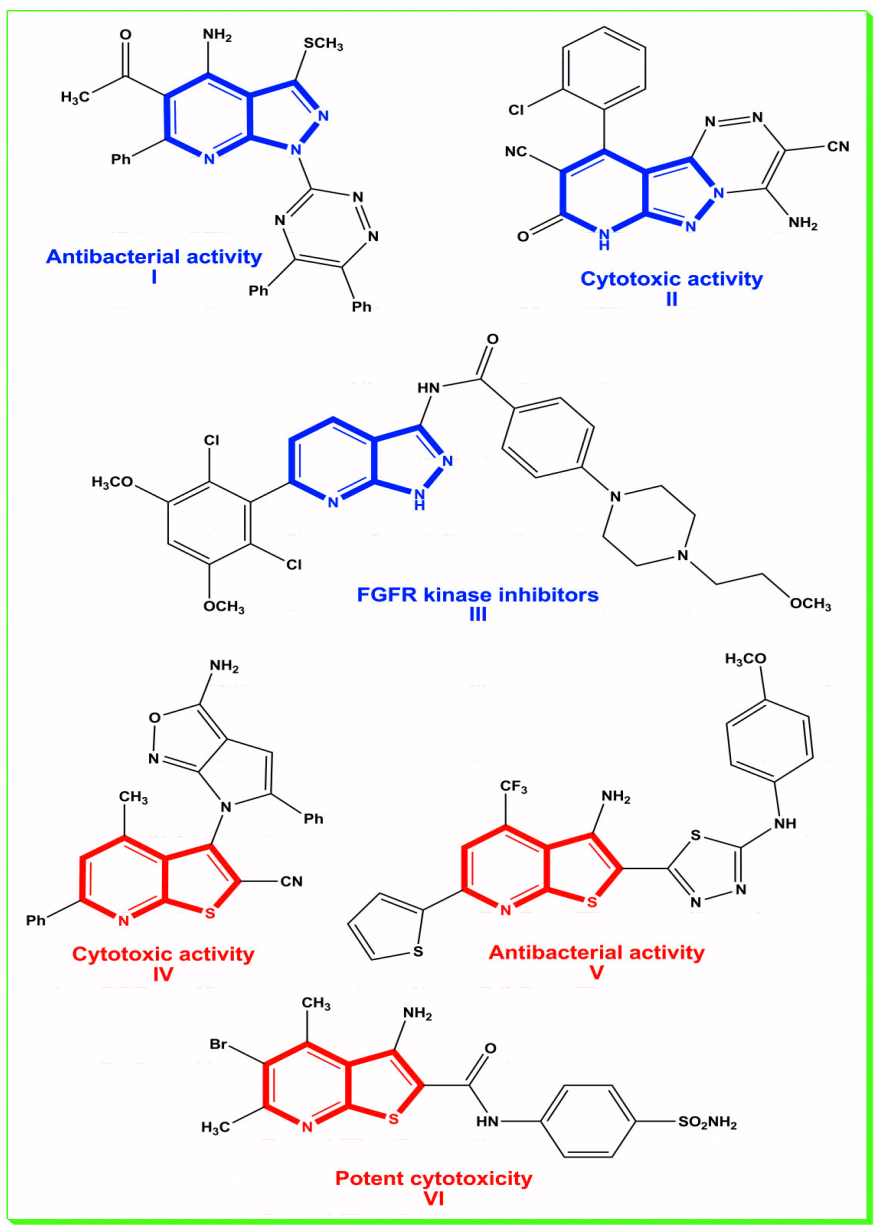

Figure 1. Pyrazolo[3,4-b]pyridines (I-III) and thieno[2,3-b]pyridines (IV-VI) with biological application.

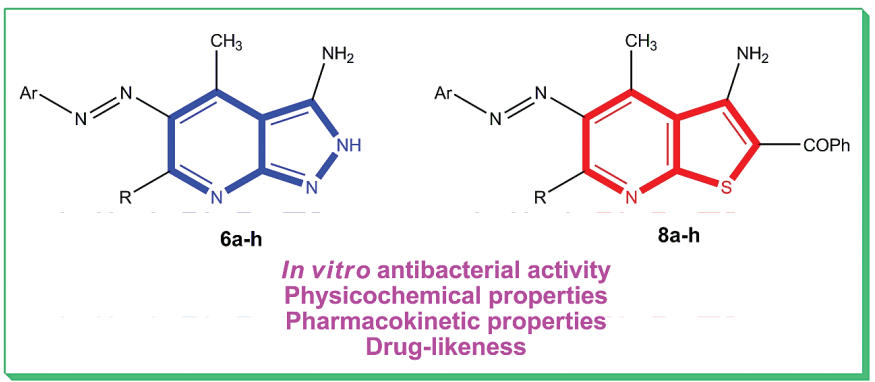

Figure 2. The compounds 6a-h and 8a-h with their studies.

From the above biological applications of pyrazolo[3,4- $b]$ pyridine and thieno[2,3-b]pyridine derivatives, the purpose of this manuscript is to evaluate the antibacterial activities of pyrazolo[3,4-b]pyridines $\mathbf{6 a - h}$ and thieno[2,3-b]pyridines 8a-h to find potent antibacterial agents. Also, the physicochemical, pharmacokinetic, and drug-likeness properties were carried out (Fig. 2).

\section{MATERIALS AND METHODS}

\section{Chemistry}

A series of pyrazolo[3,4- $b]$ pyridines $\mathbf{6 a}-\mathbf{h}$ and thieno[2,3-b]pyridines $\mathbf{8 a - h}$ were synthesized according to the reported procedure and their spectral data are shown in Table 1 (Elgemeie et al., 1993).

\section{Antibacterial activities}

In vitro antibacterial activities of pyrazolo[3,4- $b]$ pyridines $\mathbf{6 a - h}$ and thieno[2,3-b]pyridines 8a-h were measured against $B$. subtilis and $S$. aureus as Gram-positive bacteria and also against Escherichia coli and Pseudomonas aeruginosa as

Table 1. Spectral data of some pyrazolopyridines $\mathbf{6 a - h}$ and thienopyridines $\mathbf{8 a - h}$.

\begin{tabular}{|c|c|}
\hline Compounds & Spectral data \\
\hline $6 \mathbf{a}$ & $\begin{array}{l}\text { Yellow; m.p. } 295{ }^{\circ} \mathrm{C} . \mathrm{IR}(\mathrm{KBr}): v 3470,3420,3400\left(\mathrm{NH}_{2} \text { and NH) } \mathrm{cm}^{-1} .{ }^{1} \mathrm{H} \text { NMR: } \delta 2.41\left(\mathrm{~s}, 3 \mathrm{H}, \mathrm{CH}_{3}\right), 2.57\left(\mathrm{~s}, 3 \mathrm{H}, \mathrm{CH}_{3}\right), 4.82(\mathrm{~s}, b r, 2 \mathrm{H} \text {, }\right. \\
\left.\mathrm{NH}_{2}\right), 7.12-7.63\left(\mathrm{~m}, 5 \mathrm{H}, \mathrm{C}_{6} \mathrm{H}_{5}\right), 11.40(\mathrm{~s}, b r, 1 \mathrm{H}, \mathrm{NH})\end{array}$ \\
\hline $6 \mathbf{b}$ & $\begin{array}{l}\text { Red; m.p. } 270^{\circ} \mathrm{C} \text {. IR }(\mathrm{KBr}): v 3548,3404,3306,3197\left(\mathrm{NH}_{2} \text { and } \mathrm{NH}\right) \mathrm{cm}^{-1} .{ }^{1} \mathrm{H} \mathrm{NMR}: \delta 2.55\left(\mathrm{~s}, 3 \mathrm{H}, \mathrm{CH}_{3}\right), 2.63\left(\mathrm{~s}, 3 \mathrm{H}, \mathrm{CH}_{3}\right), 2.69(\mathrm{~s}, 3 \mathrm{H} \text {, } \\
\left.\mathrm{CH}_{3}\right), 5.48\left(\mathrm{~s}, b r, 2 \mathrm{H}, \mathrm{NH}_{2}\right), 7.38-7.61\left(\mathrm{~m}, 4 \mathrm{H}, \mathrm{C}_{6} \mathrm{H}_{4}\right), 12.18(\mathrm{~s}, b r, 1 \mathrm{H}, \mathrm{NH})\end{array}$ \\
\hline $6 c$ & $\begin{array}{l}\text { Buff; m.p. } 290^{\circ} \mathrm{C} . \mathrm{IR}(\mathrm{KBr}): v 3500,3420\left(\mathrm{NH}_{2} \text { and NH}\right) \mathrm{cm}^{-1} .{ }^{1} \mathrm{H} \text { NMR: } \delta 2.45\left(\mathrm{~s}, 3 \mathrm{H}, \mathrm{CH}_{3}\right), 3.58\left(\mathrm{~s}, 3 \mathrm{H}, \mathrm{CH}_{3}\right), 3.68\left(\mathrm{~s}, 3 \mathrm{H}, \mathrm{OCH}_{3}\right), \\
4.90\left(\mathrm{~s}, b r, 2 \mathrm{H}, \mathrm{NH}_{2}\right), 7.30-7.72\left(\mathrm{~m}, 4 \mathrm{H}, \mathrm{C}_{6} \mathrm{H}_{4}\right), 11.81(\mathrm{~s}, b r, 1 \mathrm{H}, \mathrm{NH})\end{array}$ \\
\hline 6d & $\begin{array}{l}\text { Orange; m.p. } 280^{\circ} \mathrm{C} \text {. IR }(\mathrm{KBr}): v 3577,3565,3414,3296\left(\mathrm{NH}_{2} \text { and } \mathrm{NH}\right) \mathrm{cm}^{-1} .{ }^{1} \mathrm{H} \mathrm{NMR}: \delta 2.64\left(\mathrm{~s}, 3 \mathrm{H}, \mathrm{CH}_{3}\right), 2.68\left(\mathrm{~s}, 3 \mathrm{H}, \mathrm{CH}_{3}\right), 5.50(\mathrm{~s}, \\
\left.b r, 2 \mathrm{H}, \mathrm{NH}_{2}\right), 7.23-7.67\left(\mathrm{~m}, 4 \mathrm{H}, \mathrm{C}_{6} \mathrm{H}_{4}\right), 12.0(\mathrm{~s}, b r, 1 \mathrm{H}, \mathrm{NH})\end{array}$ \\
\hline $6 e$ & Orange; m.p. $270^{\circ} \mathrm{C}$ \\
\hline $6 f$ & Orange; m.p. $>300^{\circ} \mathrm{C}$ \\
\hline $6 \mathrm{~g}$ & Yellow; m.p. $>300^{\circ} \mathrm{C}$ \\
\hline $6 h$ & Green; m.p. $>300^{\circ} \mathrm{C}$ \\
\hline $\mathbf{8 a}$ & $\begin{array}{l}\text { Yellow; m.p. } 225^{\circ} \mathrm{C} . \mathrm{IR}(\mathrm{KBr}): v 3577,3285\left(\mathrm{NH}_{2}\right), 1696(\mathrm{CO}) \mathrm{cm}^{-1} .{ }^{1} \mathrm{H} \text { NMR: } \delta 2.61\left(\mathrm{~s}, 3 \mathrm{H}, \mathrm{CH}_{3}\right), 2.63\left(\mathrm{~s}, 3 \mathrm{H}, \mathrm{CH}_{3}\right), 7.26(\mathrm{~s}, b r, 2 \mathrm{H}, \\
\left.\mathrm{NH}_{2}\right), 7.36-7.88\left(\mathrm{~m}, 10 \mathrm{H}, 2 \mathrm{C}_{6} \mathrm{H}_{5}\right)\end{array}$ \\
\hline $8 b$ & Red; m.p. $185^{\circ} \mathrm{C}$ \\
\hline $8 c$ & Orange; m.p. $192{ }^{\circ} \mathrm{C}$ \\
\hline 8d & $\begin{array}{l}\text { Orange; m.p. } 197^{\circ} \mathrm{C} . \mathrm{IR}(\mathrm{KBr}): v 3480,3400\left(\mathrm{NH}_{2}\right), 1680(\mathrm{CO}) \mathrm{cm}^{-1} .{ }^{1} \mathrm{H} \text { NMR: } \delta 2.57\left(\mathrm{~s}, 3 \mathrm{H}, \mathrm{CH}_{3}\right), 2.61\left(\mathrm{~s}, 3 \mathrm{H}, \mathrm{CH}_{3}\right), 7.15(\mathrm{~s}, b r, 2 \mathrm{H} \text {, } \\
\left.\mathrm{NH}_{2}\right), 7.30-7.78\left(\mathrm{~m}, 9 \mathrm{H}, \mathrm{C}_{6} \mathrm{H}_{5} \text { and } \mathrm{C}_{6} \mathrm{H}_{4}\right)\end{array}$ \\
\hline $8 e$ & $\begin{array}{l}\left.\text { Orange; m.p. } 235^{\circ} \mathrm{C} . \mathrm{IR}(\mathrm{KBr}): v 3500,3380\left(\mathrm{NH}_{2}\right), 1685(\mathrm{CO}) \mathrm{cm}^{-1} .{ }^{1} \mathrm{H} \mathrm{NMR}: \delta 2.60\left(\mathrm{~s}, 3 \mathrm{H}, \mathrm{CH}_{3}\right), 7.28(\mathrm{~s}, b r, 2 \mathrm{H}, \mathrm{NH})_{2}\right), 7.22-7.81(\mathrm{~m} \text {, } \\
\left.15 \mathrm{H}, 3 \mathrm{C}_{6} \mathrm{H}_{5}\right)\end{array}$ \\
\hline $8 f$ & Red; m.p. $220^{\circ} \mathrm{C}$ \\
\hline $8 \mathrm{~g}$ & Orange; m.p. $207^{\circ} \mathrm{C}$ \\
\hline $8 \mathbf{h}$ & $\begin{array}{l}\text { Yellow; m.p. } 240^{\circ} \mathrm{C} . \mathrm{IR}(\mathrm{KBr}): v 3500,3380\left(\mathrm{NH}_{2}\right), 1690(\mathrm{CO}) \mathrm{cm}^{-1} .{ }^{1} \mathrm{H} \text { NMR: } \delta 2.95\left(\mathrm{~s}, 3 \mathrm{H}, \mathrm{CH}_{3}\right), 7.26\left(\mathrm{~s}, b r, 2 \mathrm{H}, \mathrm{NH}_{2}\right), 7.29-7.89(\mathrm{~m}, \\
\left.14 \mathrm{H}, 2 \mathrm{C}_{6} \mathrm{H}_{5} \text { and } \mathrm{C}_{6} \mathrm{H}_{4}\right)\end{array}$ \\
\hline
\end{tabular}


Gram-negative bacteria species using a modified Kirby-Bauer disk diffusion method (Bauer et al., 1966; Osman et al., 2012). The bacteria were maintained on Meuller-Hinton agar. Dimethyl sulfoxide (DMSO) showed no inhibition zone (IZ). The agar media were incubated at $35^{\circ} \mathrm{C}-37^{\circ} \mathrm{C}$ for $24-48$ hours for bacteria such as B. subtilis, S. aureus, E. coli, and P. aeruginosa. The diameter of the IZ ( $\mathrm{mm})$ was measured. Tetracycline is used as a reference for antibacterial activities.

\section{Molecular properties prediction}

The physicochemical, pharmacokinetic, and druglikeness properties of pyrazolo[3,4- $b]$ pyridines $\mathbf{6 a}-\mathbf{h}$ and thieno[2,3-b]pyridines 8a-h were predicted using the SwissADME website (http://swissadme.ch) (Al-Wasidi et al., 2020; Elsherif et al., 2020; Naglah et al., 2020).

\section{RESULTS AND DISCUSSION}

\section{Chemistry}

The pyrazolo[3,4- $b]$ pyridines $\mathbf{6 a - h}$ and thieno[2,3- $b]$ pyridines 8a-h were prepared according to the reported method (Scheme 1) (Elgemeie et al., 1993). The reaction of 2-cyano(thio) acetamide (1) with arylhydrazones of acetylacetone 2a-d and arylhydrazones of 1-phenylbutane-1,3-dione 2e-h in EtONa/EtOH to yield the corresponding sodium salt of pyridine-2-thiolate $\mathbf{3 a - h}$. Then, the acidification of sodium salt $\mathbf{3 a - h}$ gave $1 H$-pyridine-2thione derivatives $\mathbf{4 a - h}$. There were two ways; the first way was the reaction of pyridine-2-thione $\mathbf{4 a - h}$ with $\mathrm{Cl}_{2} / \mathrm{CHCl}_{3}$ to give 2-chloropyridine 5a-h. The compounds $\mathbf{5 a - h}$ which reacted with hydrazine hydrate in refluxed ethanol gave the corresponding pyrazolo[3,4- $b]$ pyridines $\mathbf{6 a - h}$.

The structure of $\mathbf{6 a}-\mathbf{h}$ was established on the basis of spectral data. The IR spectrum of compound $\mathbf{6 d}$ shows bands at $v$ $3,577,3,565,3,414$, and $3,296 \mathrm{~cm}^{-1}$ due to $\mathrm{NH}_{2}$ and $\mathrm{NH}$ groups. Also, ${ }^{1} \mathrm{H}-\mathrm{NMR}$ of $\mathbf{6 d}$ shows a broad signal at $\delta=5.50 \mathrm{ppm}$ assigned to an $\mathrm{NH}_{2}$ group and another broad signal at $\delta=12.0 \mathrm{ppm}$ assigned to an $\mathrm{NH}$ group.

The second way was the reaction of pyridine-2-thione 4a-h with phenacyl bromide in dry ethanol to give the intermediate 7a-h which was cyclization to form the corresponding thieno[2,3- $b]$ pyridines 8a-h.

The structure of thieno[2,3-b]pyridines 8a-h was established on the basis of spectral data. The IR spectrum of 8a revealed the bands at $v 3,577$ and 3,285 for the $\mathrm{NH}_{2}$ group and the band at $v 1,696 \mathrm{~cm}^{-1}$ for the carbonyl group. The 1HNMR spectrum contained a broad signal at $\delta=7.26 \mathrm{ppm}$ assignable to an amino function and a multiplet at $\delta=7.36-7.88 \mathrm{ppm}$ assigned to the aromatic protons.

\section{Biological evaluation}

\section{In vitro antibacterial activities}

Pyrazolo[3,4- $b]$ pyridines $\mathbf{6 a - h}$ and thieno[2,3-b] pyridines 8a-h were screened in vitro for their antibacterial activities against four bacteria species (namely B. subtilis, $S$. aureus, E. coli, and $P$. aeruginosa) and compared with tetracycline as the standard drug. The results of antibacterial activities are shown in Table 2 and Figure 3, and we can found the following.

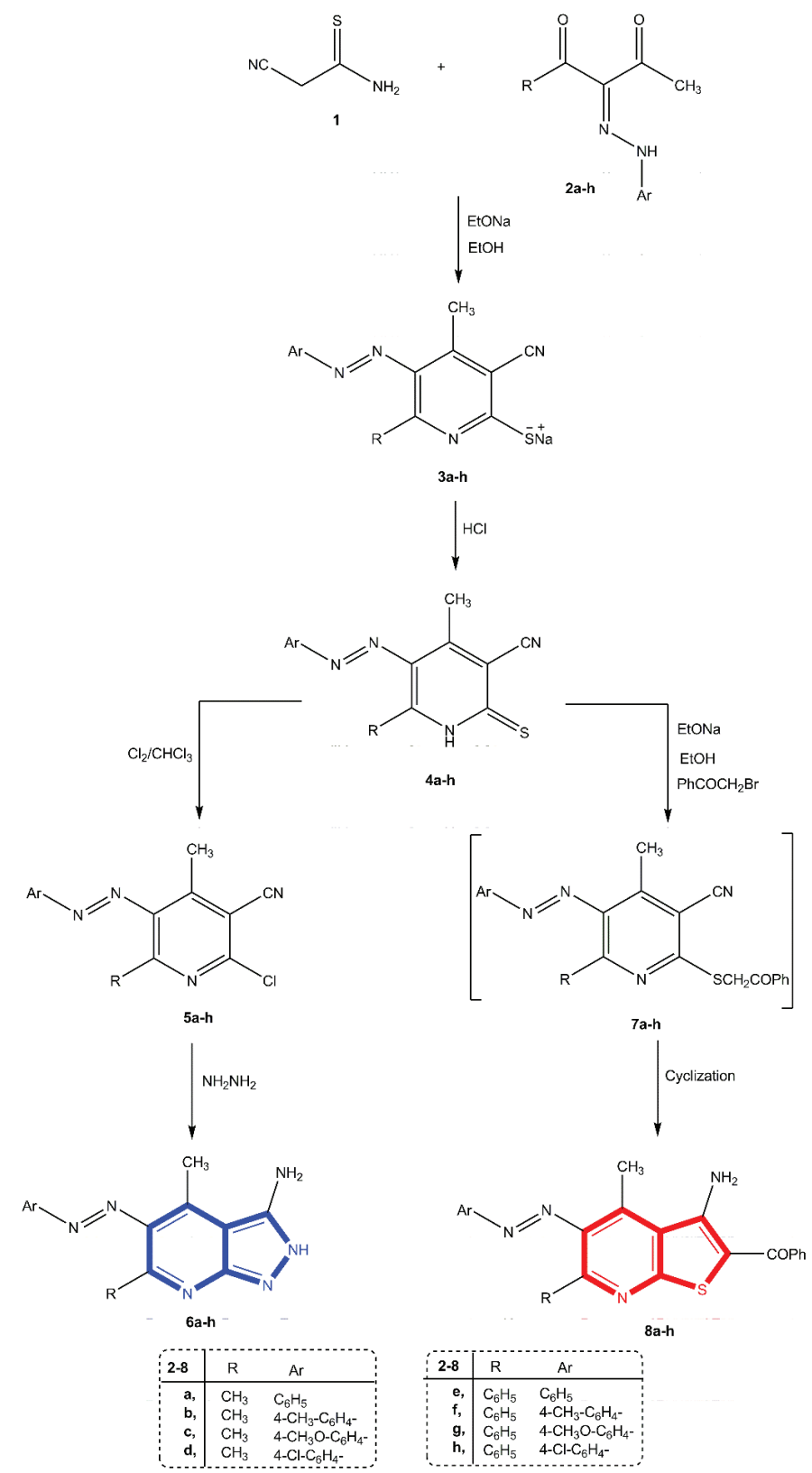

Scheme 1. Synthesis of compounds $\mathbf{6 a - h}$ and $\mathbf{8 a - h}$.

The six pyrazolo $[3,4-b]$ pyridine derivatives $(\mathbf{6} \mathbf{a}, \mathbf{6 b}, \mathbf{6 c}$, $\mathbf{6 d}, \mathbf{6 g}$, and $\mathbf{6 h}$ ) and two thieno[2,3-b]pyridines (8a and 8e) exhibit moderate antibacterial activities IZ rang: $12-14 \mathrm{~mm}$ ) against Gram-positive $B$. subtilis bacterial and the rest derivatives show weak activities $(\mathrm{IZ} \leq 11 \mathrm{~mm})$.

The three derivatives $(\mathbf{6 b}, \mathbf{8 c}$, and $\mathbf{8 g})$ exhibit moderate activities $(\mathrm{IZ}=12 \mathrm{~mm})$ against $S$. aureus

In the case of $E$. coli Gram-negative bacterial, only three pyrazolo $[3,4-b]$ pyridine derivatives $(\mathbf{6 b}, \mathbf{6 d}$, and $\mathbf{6 h})$ show moderate activities (IZ $=13,16$, and $12 \mathrm{~mm}$, resp.).

For $P$. aeruginosa bacterial, the pyrazolo $[3,4-b]$ pyridine derivative $\mathbf{6 h}(\mathrm{IZ}=13 \mathrm{~mm})$ and two thieno[2,3-b]pyridines $\{\mathbf{8 f}(\mathrm{IZ}$ $=12 \mathrm{~mm})$ and $\mathbf{8 g}(\mathrm{IZ}=13 \mathrm{~mm})\}$ display moderate activities. 
Table 2. In vitro antibacterial activities [IZ in millimeters $(\mathrm{mm})]$ of pyrazolo[3,4-b]pyridines 6a-h and thieno[2,3-b]pyridines 8a-h.

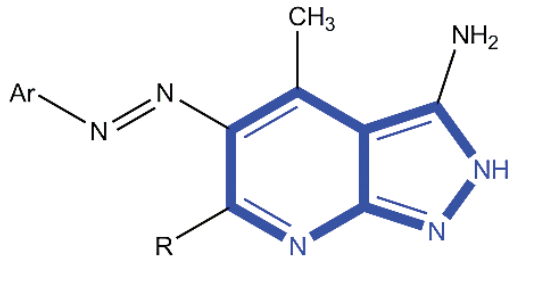

6a-h

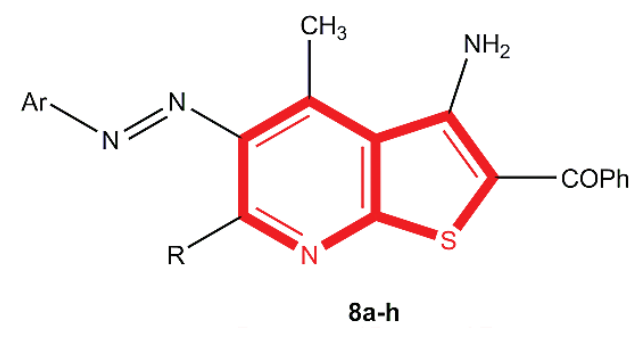

\begin{tabular}{|c|c|c|c|c|c|c|}
\hline \multirow{2}{*}{ Compounds } & \multirow{2}{*}{$\mathbf{R}$} & \multirow{2}{*}{ Ar } & \multicolumn{2}{|c|}{ Gram-positive } & \multicolumn{2}{|c|}{ Gram-negative } \\
\hline & & & B. subtilis & S. aureus & E. coli & P. aeruginosa \\
\hline $6 \mathbf{a}$ & $\mathrm{CH}_{3}$ & $\mathrm{C}_{6} \mathrm{H}_{5}$ & 14 & 10 & 11 & 9 \\
\hline $6 b$ & $\mathrm{CH}_{3}$ & $4-\mathrm{CH}_{3}-\mathrm{C}_{6} \mathrm{H}_{4}$ & 14 & 12 & 13 & 11 \\
\hline $6 c$ & $\mathrm{CH}_{3}$ & $4-\mathrm{CH}_{3} \mathrm{O}-\mathrm{C}_{6} \mathrm{H}_{4}$ & 12 & 8 & 7 & 9 \\
\hline $6 d$ & $\mathrm{CH}_{3}$ & 4-Cl- $\mathrm{C}_{6} \mathrm{H}_{4}$ & 12 & 9 & 16 & 8 \\
\hline $6 e$ & $\mathrm{C}_{6} \mathrm{H}_{5}$ & $\mathrm{C}_{6} \mathrm{H}_{5}$ & 9 & 11 & 10 & 7 \\
\hline 6f & $\mathrm{C}_{6} \mathrm{H}_{5}$ & $4-\mathrm{CH}_{3}-\mathrm{C}_{6} \mathrm{H}_{4}$ & 8 & 10 & 8 & 9 \\
\hline $6 \mathrm{~g}$ & $\mathrm{C}_{6} \mathrm{H}_{5}$ & $4-\mathrm{CH}_{3} \mathrm{O}-\mathrm{C}_{6} \mathrm{H}_{4}$ & 12 & 11 & 7 & 11 \\
\hline $6 h$ & $\mathrm{C}_{6} \mathrm{H}_{5}$ & 4-Cl- $\mathrm{C}_{6} \mathrm{H}_{4}$ & 12 & 8 & 12 & 13 \\
\hline $8 \mathbf{a}$ & $\mathrm{CH}_{3}$ & $\mathrm{C}_{6} \mathrm{H}_{5}$ & 12 & 10 & 10 & 10 \\
\hline $8 b$ & $\mathrm{CH}_{3}$ & 4- $\mathrm{CH}_{3}-\mathrm{C}_{6} \mathrm{H}_{4}$ & 8 & 11 & 8 & 9 \\
\hline $8 c$ & $\mathrm{CH}_{3}$ & $4-\mathrm{CH}_{3} \mathrm{O}-\mathrm{C}_{6} \mathrm{H}_{4}$ & 10 & 12 & 10 & 6 \\
\hline $8 d$ & $\mathrm{CH}_{3}$ & 4-Cl- $\mathrm{C}_{6} \mathrm{H}_{4}$ & 7 & 10 & 7 & 10 \\
\hline $8 \mathrm{e}$ & $\mathrm{C}_{6} \mathrm{H}_{5}$ & $\mathrm{C}_{6} \mathrm{H}_{5}$ & 12 & 11 & 10 & 9 \\
\hline $8 f$ & $\mathrm{C}_{6} \mathrm{H}_{5}$ & $4-\mathrm{CH}_{3}-\mathrm{C}_{6} \mathrm{H}_{4}$ & 9 & 8 & 10 & 12 \\
\hline $8 g$ & $\mathrm{C}_{6} \mathrm{H}_{5}$ & $4-\mathrm{CH}_{3} \mathrm{O}-\mathrm{C}_{6} \mathrm{H}_{4}$ & 7 & 12 & 11 & 13 \\
\hline $8 h$ & $\mathrm{C}_{6} \mathrm{H}_{5}$ & 4-Cl- $\mathrm{C}_{6} \mathrm{H}_{4}$ & 7 & 10 & 7 & 9 \\
\hline Tetracycline & & - & 32 & 30 & 32 & 34 \\
\hline
\end{tabular}

$\mathrm{IZ} \geq 20 \mathrm{~mm}$ high activity; IZ: 19-12 $\mathrm{mm}$ moderate activity; IZ $\leq 11 \mathrm{~mm}$ weak activity.

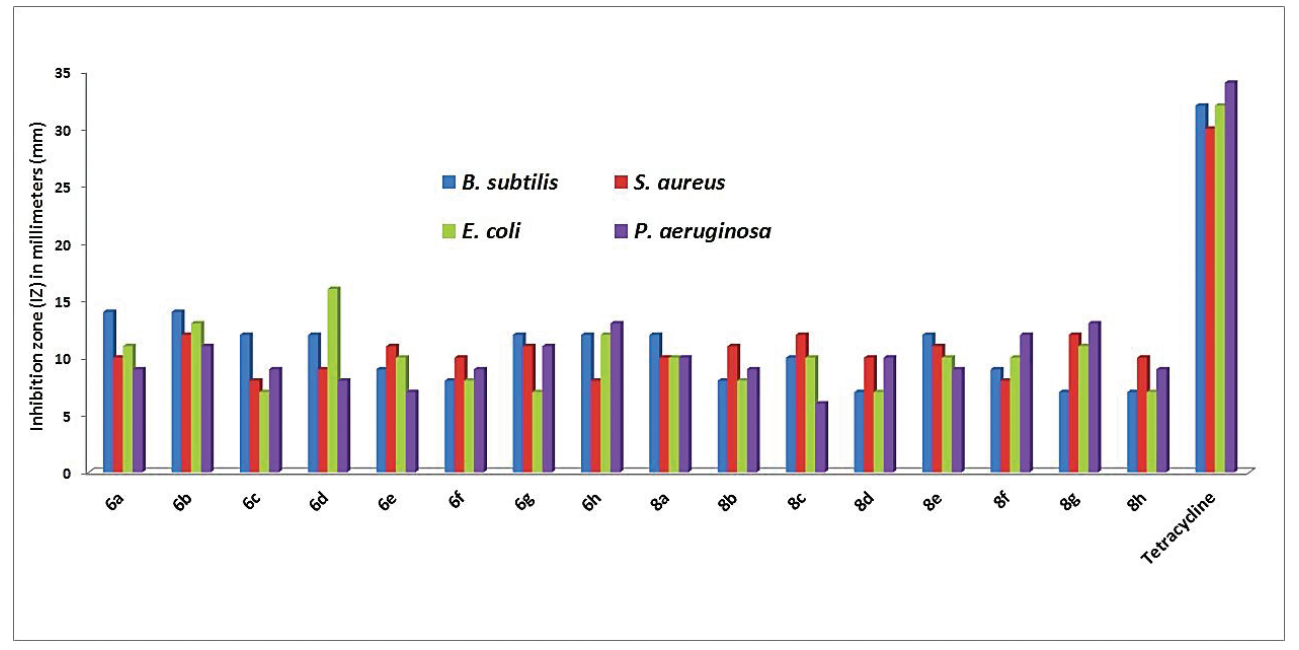

Figure 3. Antibacterial activities of pyrazolo[3,4- $b]$ pyridines $\mathbf{6 a - h}$ and thieno[2,3-b]pyridines 8a-h and tetracycline against four bacteria species.

Finally, most of pyrazolo[3,4-b]pyridines and thieno[2,3-b]pyridines are moderately active. Therefore, in the future, we will modify, design, and prepare a new pyrazolo[3,4-b] pyridines and thieno[2,3-b]pyridines to obtain and find more active antibacterial agents.

\section{Molecular properties}

Physicochemical properties

The results of the computed physicochemical properties of the pyrazolo[3,4- $b]$ pyridines $\mathbf{6} \mathbf{a}-\mathbf{h}$ and thieno[2,3-b]pyridines $\mathbf{8 a - h}$ are shown in Table 3. 
Table 3. Physicochemical properties of pyrazolo $[3,4-b]$ pyridines $\mathbf{6 a - h}$ and thieno[2,3-b]pyridines 8a-h

\begin{tabular}{|c|c|c|c|c|c|c|c|c|}
\hline \multirow{2}{*}{ Compounds } & \multirow{2}{*}{ MW } & \multirow{2}{*}{$n \mathrm{HBA}$} & \multirow{2}{*}{$n \mathrm{HBD}$} & \multirow{2}{*}{$n \mathrm{RB}$} & \multirow{2}{*}{ TPSA $\left(\AA^{2}\right)$} & \multicolumn{2}{|c|}{ Lipophilicity } & \multirow{2}{*}{$\begin{array}{c}\text { Fraction } \\
\text { Csp3 }\end{array}$} \\
\hline & & & & & & $M \log \mathrm{P}$ & XLOGP3 & \\
\hline Rule & $<500$ & $\leq 10$ & $\leq 5$ & $\leq 9$ & 20 to130 & $\leq 4.15$ & -0.7 to +5.0 & $\geq 0.25$ \\
\hline $6 a$ & 266.30 & 4 & 2 & 2 & 92.31 & 1.92 & 3.01 & 0.14 \\
\hline $6 \mathrm{~b}$ & 280.33 & 4 & 2 & 2 & 92.31 & 2.18 & 3.37 & 0.20 \\
\hline $6 c$ & 296.33 & 5 & 2 & 2 & 101.54 & 1.65 & 2.98 & 0.20 \\
\hline 6d & 300.75 & 4 & 2 & 2 & 92.31 & 2.45 & 3.64 & 0.14 \\
\hline $6 e$ & 328.37 & 4 & 2 & 3 & 92.31 & 2.92 & 4.27 & 0.05 \\
\hline $6 f$ & 342.40 & 4 & 2 & 3 & 92.31 & 3.15 & 4.64 & 0.10 \\
\hline $6 \mathrm{~g}$ & 358.40 & 5 & 2 & 4 & 101.54 & 2.62 & 4.24 & 0.10 \\
\hline $6 \mathrm{~h}$ & 362.82 & 4 & 2 & 3 & 92.31 & 3.42 & 4.90 & 0.05 \\
\hline $8 a$ & 384.47 & 4 & 1 & 4 & 108.94 & 2.98 & 6.29 & 0.09 \\
\hline $8 b$ & 400.50 & 4 & 1 & 4 & 108.94 & 3.19 & 6.66 & 0.13 \\
\hline $8 \mathrm{c}$ & 416.50 & 5 & 1 & 5 & 118.17 & 2.38 & 6.26 & 0.13 \\
\hline $8 d$ & 420.91 & 4 & 1 & 4 & 108.94 & 3.19 & 6.92 & 0.09 \\
\hline $8 \mathrm{e}$ & 448.54 & 4 & 1 & 5 & 108.94 & 3.82 & 7.55 & 0.04 \\
\hline $8 f$ & 462.57 & 4 & 1 & 5 & 108.94 & 4.01 & 7.92 & 0.07 \\
\hline $8 \mathrm{~g}$ & 478.56 & 5 & 1 & 6 & 118.17 & 3.20 & 7.52 & 0.07 \\
\hline $8 \mathrm{~h}$ & 482.98 & 4 & 1 & 5 & 108.94 & 4.01 & 8.18 & 0.04 \\
\hline
\end{tabular}

$\mathrm{MW}=$ molecular weight; $n \mathrm{HBA}=$ number of hydrogen bond acceptors; $n \mathrm{HBD}=$ number of hydrogen bond donors; $n \mathrm{RB}=$ number of rotatable bonds; TPSA $=$ total polar surface area.

Drug-likeness was used for finding the oral drug candidates and was established based on the physicochemical properties. Lipinski's filter and Veber's filter are rule-based filters (Daina et al., 2017; Hassan et al., 2020; Lipinski et al., 2001; Veber et al., 2002).

From Table 3, all the pyrazolopyridines $\mathbf{6 a}-\mathbf{h}$ and thienopyridines 8a-h showed agreement to Lipinski's rule and Veber's rule. Therefore, the two series 6a-h and 8a-h may be used as oral drug candidates.

The bioavailability radar of the pyrazolo[3,4- $b]$ pyridines $\mathbf{6 a - h}$ and thieno[2,3-b]pyridines 8a-h displayed a rapid evaluation of drug-likeness.

The bioavailability radar was including lipophilicity, size, polarity, solubility, saturation, and flexibility of the physicochemical properties.

The optimal range of these properties was presented by the pink area (Lovering et al., 2009; Ritchie et al., 2011) and the properties of pyrazolo $[3,4-b]$ pyridines $\mathbf{6 a}-\mathbf{h}$ and thieno[2,3-b] pyridines $\mathbf{8} \mathbf{a}-\mathbf{h}$ were presented by the red line.

From this study, we can conclude that the red line of two pyrazolo[3,4-b]pyridines $\mathbf{6} \mathbf{b}$ and $\mathbf{6 c}$ is almost in the range of the pink area. Therefore, the two compounds are nearly predicted orally bioavailable (Fig. 4a and b) and we will modify them to obtain more active antibacterial agents.

\section{Pharmacokinetic properties}

The results of the pharmacokinetic properties of pyrazolo $[3,4-b]$ pyridines $\mathbf{6 a}-\mathbf{h}$ and thieno[2,3-b]pyridines $\mathbf{8 a - h}$ are shown in Table 4; we can see the following:

All the pyrazolo[3,4-b]pyridine derivatives $\mathbf{6 a}-\mathbf{h}$ show high gastrointestinal absorption. But, the thieno[2,3-b]pyridines 8a-h show low GI absorption.

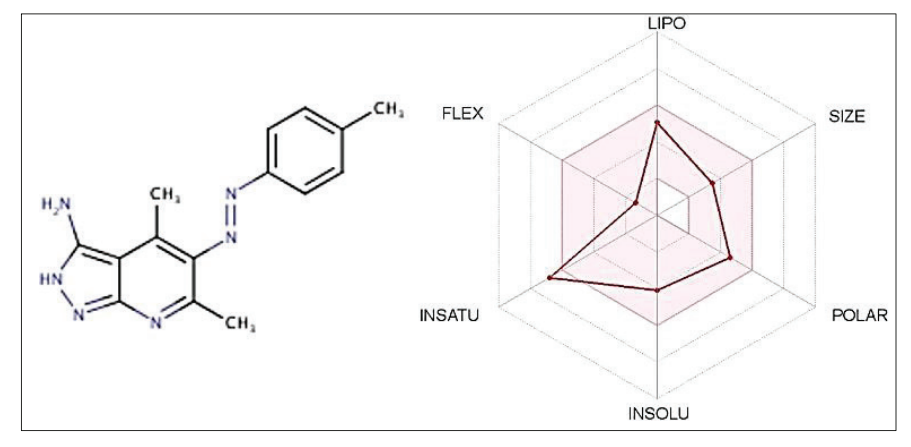

a

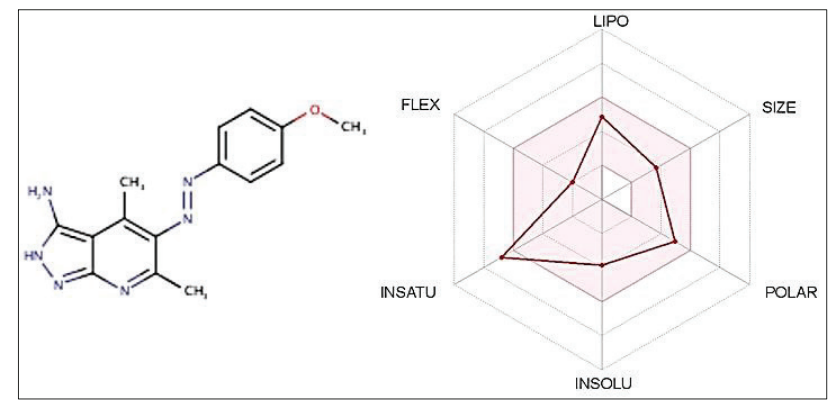

b

Figure 4. (a) The bioavailability radar of derivative $\mathbf{6 b}$. (b) The bioavailability radar of derivative $\mathbf{6 c}$.

All the pyrazolo $[3,4-b]$ pyridines $\mathbf{6 a}-\mathbf{h}$ and thieno[2,3- $b]$ pyridines 8a-h are not predicted to penetrate the blood-brain barrier (BBB). 
Table 4. Pharmacokinetic properties of pyrazolo[3,4-b]pyridines 6a-h and thieno[2,3-b]pyridines 8a-h.

\begin{tabular}{|c|c|c|c|c|c|c|c|c|}
\hline \multirow[b]{2}{*}{ Compounds } & \multirow[b]{2}{*}{ GI absorption } & \multirow[b]{2}{*}{ BBB permeability } & \multirow{2}{*}{$\begin{array}{c}\text { P-gp } \\
\text { substrate }\end{array}$} & \multicolumn{5}{|c|}{ CYP isoenzymes } \\
\hline & & & & $\begin{array}{l}\text { CYP1A2 } \\
\text { inhibitor }\end{array}$ & $\begin{array}{l}\text { CYP2C19 } \\
\text { inhibitor }\end{array}$ & $\begin{array}{l}\text { CYP2C9 } \\
\text { inhibitor }\end{array}$ & $\begin{array}{l}\text { CYP2D6 } \\
\text { inhibitor }\end{array}$ & CYP3A4 inhibitor \\
\hline $\mathbf{6 a}$ & High & No & No & Inhibitor & Inhibitor & Non-inhibitor & Non-inhibitor & Non-inhibitor \\
\hline $6 b$ & High & No & No & Inhibitor & Inhibitor & Non-inhibitor & Non-inhibitor & Non-inhibitor \\
\hline $6 c$ & High & No & Yes & Inhibitor & Non-inhibitor & Non-inhibitor & Non-inhibitor & Non-inhibitor \\
\hline 6d & High & No & No & Inhibitor & Inhibitor & Non-inhibitor & Non-inhibitor & Non-inhibitor \\
\hline $6 e$ & High & No & No & Inhibitor & Inhibitor & Non-inhibitor & Non-inhibitor & Non-inhibitor \\
\hline $6 f$ & High & No & No & Inhibitor & Inhibitor & Non-inhibitor & Non-inhibitor & Non-inhibitor \\
\hline $6 \mathrm{~g}$ & High & No & No & Inhibitor & Inhibitor & Inhibitor & Non-inhibitor & Non-inhibitor \\
\hline $6 h$ & High & No & No & Inhibitor & Inhibitor & Non-inhibitor & Non-inhibitor & Non-inhibitor \\
\hline 8a & Low & No & No & Non-inhibitor & Inhibitor & Inhibitor & Non-inhibitor & Non-inhibitor \\
\hline $8 b$ & Low & No & No & Non-inhibitor & Inhibitor & Inhibitor & Non-inhibitor & Non-inhibitor \\
\hline $8 c$ & Low & No & No & Non-inhibitor & Inhibitor & Inhibitor & Non-inhibitor & Non-inhibitor \\
\hline $8 d$ & Low & No & No & Non-inhibitor & Inhibitor & Inhibitor & Non-inhibitor & Non-inhibitor \\
\hline $8 e$ & Low & No & No & Non-inhibitor & Inhibitor & Non-inhibitor & Non-inhibitor & Non-inhibitor \\
\hline $8 f$ & Low & No & No & Non-inhibitor & Non-inhibitor & Non-inhibitor & Non-inhibitor & Non-inhibitor \\
\hline $8 g$ & Low & No & No & Non-inhibitor & Non-inhibitor & Non-inhibitor & Non-inhibitor & Non-inhibitor \\
\hline $8 h$ & Low & No & No & Non-inhibitor & Non-inhibitor & Non-inhibitor & Non-inhibitor & Non-inhibitor \\
\hline
\end{tabular}

$\mathrm{GI}=$ gastrointestinal absorption; $\mathrm{BBB}$ = blood-brain barrier; P-gp = P-glycoprotein.

All the derivatives, pyrazolo[3,4-b]pyridines $\mathbf{6 a - h}$ and thieno[2,3-b]pyridines $\mathbf{8} \mathbf{a}-\mathbf{h}$, are non-substrates for P-glycoprotein (P-gp) except the derivative 6c (substrates for P-glycoprotein). Therefore, they have no effect on the central nervous system.

Inhibition of the five major CYP isoforms (CYP1A2, CYP2C19, CYP2C9, CYP2D6, and CYP3A4) is certainly one major cause of pharmacokinetic-related drug-drug interactions. The pyrazolo[3,4-b]pyridine derivatives $\mathbf{6 a}-\mathbf{h}$ are inhibitors of the CYP1A2 enzyme, while the thieno[2,3-b]pyridine compounds $\mathbf{8 a}-\mathbf{h}$ are non-inhibitors. All compounds, 6a-h and $\mathbf{8 a - h}$, are inhibitors of the CYP2C19 enzyme except the four derivatives $\mathbf{6 c}, \mathbf{8 f}, \mathbf{8 g}$, and $\mathbf{8 h}$ that are Non-inhibitor. The five compounds, pyrazolo[3,4- $b]$ pyridine $\mathbf{6 g}$ and thieno[2,3-b]pyridines $\mathbf{8 a - d}$, are inhibitors of the CYP2C9 enzyme and the rest of the derivatives are non-inhibitors. The two series, pyrazolo[3,4-b]pyridine $\mathbf{6 g}$ and thieno[2,3-b]pyridines 8a-d, are non-inhibitors of CYP2D6 and CYP3A4 enzymes (Daina et al., 2017).

\section{CONCLUSION}

In this manuscript, a series of pyrazolo[3,4-b]pyridines (6a-h) and thieno[2,3-b]pyridines $(\mathbf{8 a}-\mathbf{h})$ were synthesized for evaluation of their in vitro antibacterial activities against four bacteria species, namely, B. subtilis, S. aureus, E. coli, and $P$. aeruginosa. In general, some of pyrazolo[3,4-b]pyridines and thieno[2,3-b]pyridines display moderate antibacterial activities. Furthermore, the result of physicochemical, pharmacokinetic, and drug-likeness properties studies show that (i) all the pyrazolopyridines $\mathbf{6 a}-\mathbf{h}$ and thienopyridines $\mathbf{8 a}-\mathbf{h}$ fulfill the requirements of Lipinski and Veber rules and (ii) the two pyrazolo[3,4-b]pyridine derivatives (6b and $\mathbf{6 c}$ ) almost are predicted orally bioavailable. Also, pyrazolo[3,4-b]pyridine derivatives 6a-h show high gastrointestinal absorption, only the derivative $\mathbf{6 c}$ is substrates for P-glycoprotein, and most of the pyrazolopyridines $\mathbf{6 a - h}$ and thienopyridines $\mathbf{8 a - h}$ show CYP isoforms inhibition.
In the future, these results provide the lead for the design of new derivatives of pyrazolo[3,4-b]pyridine and thieno[2,3- $b]$ pyridine with advanced studies to obtain more potent antibacterial agents.

\section{AUTHOR CONTRIBUTIONS}

All authors made substantial contributions to conception and design, acquisition of data, or analysis and interpretation of data; took part in drafting the article or revising it critically for important intellectual content; agreed to submit to the current journal; gave final approval of the version to be published; and agree to be accountable for all aspects of the work. All the authors are eligible to be an author as per the international committee of medical journal editors (ICMJE) requirements/guidelines.

\section{FUNDING}

There is no funding to report.

\section{CONFLICTS OF INTEREST}

The authors report no financial or any other conflicts of interest in this work.

\section{ETHICAL APPROVALS}

This study does not involve experiments on animals or human subjects.

\section{PUBLISHER'S NOTE}

This journal remains neutral with regard to jurisdictional claims in published institutional affiliation.

\section{REFERENCES}

Abd El-All AS, Hassan AS, Osman SA, Yosef HAA, Abdel-Hady WH, El-Hashash MA, Atta-Allah SR, Ali MM, El Rashedy AA. Synthesis, characterization and biological evaluation of new fused triazine derivatives based on 6-methyl-3-thioxo-1,2,4-triazin-5-one. Acta Pol Pharm, 2016; $73: 79$ 
Adole VA, More RA, Jagdale BS, Pawar TB, Chobe SS. Efficient synthesis, antibacterial, antifungal, antioxidant and cytotoxicity study of 2-(2-Hydrazineyl)thiazole derivatives. ChemistrySelect, 2020; 5:2778-86; doi:10.1002/slct.201904609

Ali TES. Synthesis of some novel pyrazolo[3,4-b]pyridine and pyrazolo[3,4-d]pyrimidine derivatives bearing 5,6-diphenyl-1,2,4-triazine moiety as potential antimicrobial agents. Eur J Med Chem. 2009; 44:4385; doi:10.1016/j.ejmech.2009.05.031

Al-Wasidi AS, Hassan AS, Naglah AM. In vitro cytotoxicity and drug-likeness of pyrazolines and pyridines bearing benzofuran moiety. $\mathrm{J}$ Appl Pharm Sci, 2020; 10:142; doi:10.7324/JAPS.2020.104018

Bauer AW, Kirby WWM, Sherris JC, Turck M. Antibiotic susceptibility testing by a tandardized single disc method. Am J Clin Pathol. 1966; 45:493; doi:10.1093/ajcp/45.4_ts.493

Chobe SS, Adole VA, Deshmukh KP, Pawar TB, Jagdale, BS. Poly (ethylene glycol)(PEG-400): a green approach towards synthesis of novel pyrazolo [3,4- $d]$ pyrimidin-6-amines derivatives and their antimicrobial screening. Arch Appl Sci Res, 2014; 6:61.

Daina A, Michielin O, Zoete V. SwissADME: a free web tool to evaluate pharmacokinetics, drug-likeness and medicinal chemistry friendliness of small molecules. Sci Rep, 2017; 7:42717; doi:10.1038/ srep42717

Elgemeie GEH, El-Zanate AM, Mansour AKE. Reaction of (cyano)thioacetamide with arylhydrazones of $\beta$-diketones: novel synthesis of 2(1H)-pyridinethiones, thieno[2,3-b]pyridines, and pyrazolo[3,4-b] pyridines. Bull Chem Soc Jpn, 1993; 66:555.

El-Naggar M, Hassan AS, Awad HM, Mady MF. Design, synthesis and antitumor evaluation of novel pyrazolopyrimidines and pyrazoloquinazolines. Molecules, 2018; 23:1249; doi:10.3390/ molecules23061249

Elneairy MAA, Attaby FA, Elsayed MS. Synthesis of thiazole, triazole, pyrazolo[3,4-b]-pyridinyl-3-phenylthiourea, aminopyrazolo[3,4-b] pyridine derivatives and their biological evaluation. Phosphorus Sulfur Silicon Relat Elem, 2000; 167:161; doi:10.1080/10426500008082396

Elsherif MA, Hassan AS, Moustafa GO, Awad HM, Morsy NM. Antimicrobial evaluation and molecular properties prediction of pyrazolines incorporating benzofuran and pyrazole moieties. J Appl Pharm Sci, 2020; 10:37; doi:10.7324/JAPS.2020.102006

Hassan AS, Askar AA, Naglah AM, Almehizia AA, Ragab A. Discovery of new schiff bases tethered pyrazole moiety: design, synthesis, biological evaluation, and molecular docking study as dual targeting DHFR/ DNA gyrase inhibitors with immunomodulatory activity. Molecules, 2020; 25:2593; doi:10.3390/molecules25112593

Hassan AS, Awad HM, Magd-El-Din AA, Hafez TS. Synthesis and in vitro antitumor evaluation of novel Schiff bases. Med Chem Res, 2018; 27:915; doi:10.1007/s00044-017-2113-5

Hassan AS, Hafez TS, Ali MM, Khatab TK. Design, synthesis and cytotoxic activity of some new pyrazolines bearing benzofuran and pyrazole moieties. Res J Pharm Biol Chem Sci, 2016; 7:417.

Hassan AS, Moustafa GO, Awad HM. Synthesis and in vitro anticancer activity of pyrazolo[1,5-a]pyrimidines and pyrazolo[3,4-d] [1,2,3]triazines. Synth Commun 2017; 47:1963; doi:10.1080/00397911.20 17.1358368

Hassan AY, Sarg MT, El-Sebaey SA. Synthesis and antitumor evaluation of some new derivatives and fused heterocyclic compounds derived from thieno[2,3-b]pyridine. J Heterocycl Chem, 2019; 56:3102; doi:10.1002/jhet.3709

Jian XE, Yang F, Jiang CS, You WW, Zhao PL. Synthesis and biological evaluation of novel pyrazolo $[3,4-b]$ pyridines as cis-restricted combretastatin A-4 analogues. Bioorg Med Chem Lett, 2020; 30:127025; doi:10.1016/j.bmcl.2020.127025

Kumar GS, Poornachandra Y, Reddy KR, Kumar CG, Narsaiah B. Synthesis of novel triazolothione, thiadiazole, triazole-functionalized furo/thieno[2,3-b]pyridine derivatives and their antimicrobial activity. Synth Commun, 2017; 47:1864; doi:10.1080/00397911.2017.1354379
Lipinski CA, Lombardo F, Dominy BW, Feeney PJ. Experimental and computational approaches to estimate solubility in drug discovery and development settings. Adv Drug Deliv Rev, 2001; 46:3; doi:10.1016/ S0169-409X(00)00129-0

Lovering F, Bikker J, Humblet C. Escape from Flatland: increasing saturation as an approach to improving clinical success. J Med Chem, 2009; 52:6752; doi:10.1021/jm901241e

Magd-El-Din AA, Mousa HA, Labib AA, Hassan AS, Abd El-All AS, Ali MM, El-Rashedy AA, El-Desoky AH. Benzimidazole-schiff bases and their complexes: synthesis, anticancer activity and molecular modeling as Aurora kinase inhibitor. Z Naturforsch C, 2018; 73:465; doi:10.1515/ znc-2018-0010

Mohi-El-Deen EM, Abd El-Meguid EA, Hasabelnaby S, Karam EA, Nossier ES. Synthesis, docking studies, and In vitro evaluation of some novel thienopyridines and fused thienopyridine-quinolines as antibacterial agents and DNA gyrase inhibitors. Molecules, 2019; 24:3650; doi:10.3390/ molecules 24203650

Nafie MS, Amer AM, Mohamed AK, Tantawy ES. Discovery of novel pyrazolo[3,4-b]pyridine scaffold-based derivatives as potential PIM1 kinase inhibitors in breast cancer MCF-7 cells. Bioorg Med Chem, 2020; 28:115828; doi:10.1016/j.bmc.2020.11582

Naglah AM, Askar AA, Hassan AS, Khatab TK, Al-Omar MA, Bhat MA. Biological evaluation and molecular docking with in silico physicochemical, pharmacokinetic and toxicity prediction of pyrazolo[1,5-a]pyrimidines. Molecules, 2020; 25:1431; doi:10.3390/ molecules 25061431

Naguib BH, El-Nassan HB. Synthesis of new thieno[2,3-b] pyridine derivatives as pim-1 inhibitors. J Enzyme Inhib Med Chem, 2016; 31:1718; doi:10.3109/14756366.2016.1158711

Osman SA, Yosef HAA, Hafez TS, El-Sawy AA, Mousa HA, Hassan AS. Synthesis and antibacterial activity of some novel chalcones, pyrazoline and 3-cyanopyridine derivatives based on khellinone as well as $\mathrm{Ni}(\mathrm{II}), \mathrm{Co}(\mathrm{II})$ and Zn(II) complexes. Aust J Basic Appl Sci, 2012; 6:852.

Ravula S, Bobbala RR, Kolli B. Synthesis of novel isoxazole functionalized pyrazolo[3,4-b]pyridine derivatives; their anticancer activity. J Heterocycl Chem, 2020; 57:2535; doi:10.1002/jhet.3968

Ritchie TJ, Ertl P, Lewis R. The graphical representation of ADME-related molecule properties for medicinal chemists. Drug Discov Today, 2011; 16:65; doi: 10.1016/j.drudis.2010.11.002

Saeedi M, Safavi M, Allahabadi E, Rastegari A, Hariri R, Jafari S, Bukhari SNA, Mirfazli SS, Firuzi O, Edraki N, Mahdavi M, Akbarzadeh T. Thieno[2,3-b]pyridine amines: synthesis and evaluation of tacrine analogs against biological activities related to Alzheimer's disease. Arch Pharm, 2020; 353:e2000101; doi:10.1002/ardp.202000101

Shaaban OG, Issa DAE, El-Tombary AA, Abd El Wahab SM, Abdel Wahab AE, Abdelwahab IA. Synthesis and molecular docking study of some 3,4-dihydrothieno[2,3-d]pyrimidine derivatives as potential antimicrobial agents. Bioorg Chem, 2019; 88:102934; doi:10.1016/j. bioorg.2019.102934

Veber DF, Johnson SR, Cheng HY, Smith BR, Ward KW, Kopple $\mathrm{KD}$. Molecular properties that influence the oral bioavailability of drug candidates. J Med Chem, 2002; 45:2615; doi:10.1021/jm020017n

Zhao B, Li Y, Xu P, Dai Y, Luo C, Sun Y, Ai J, Geng M, Duan W. Discovery of substituted $1 H$-pyrazolo $[3,4-b]$ pyridine derivatives as potent and selective FGFR kinase inhibitors. ACS Med Chem Lett, 2016; 7(6):629; doi:10.1021/acsmedchemlett.6b00066

How to cite this article:

Elsherif MA. Antibacterial evaluation and molecular properties of pyrazolo[3,4- $b]$ pyridines and thieno[2,3- $b]$ pyridines. J Appl Pharm Sci, 2021; 11(06):118-124. 